\title{
ЕФЕКТИВНІСТЬ ПРЕПАРАТІВ ЕLITE ZОО ДОГ ТА ЕLITE ZOO КЕТ НА ГЕЛЬМІНТОФАУНУ ДРІБНИХ ДОМАШНІХ ТВАРИН
}

\author{
Березовський Андрій Володимирович \\ доктор ветеринарних наук, професор \\ Сумський національний аграрний університет (м. Суми, Україна) \\ ORCID: 0000-0002-5825-9504 \\ bav13@meta.ua \\ Морозов Богдан Станіславович \\ аспірант ${ }^{1}$ \\ Сумський національний аграрний університет (м. Суми, Україна) \\ ORCID: 0000-0002-6755-752X \\ MorozovBS@meta.ua
}

У статті наведені дані щодо ефекттивності застосування препаратів ELITE ZOO ДОГ та ELITE ZOO KET (виробник Україна ООО фірма ПРОДУКТ) для лікування собак і котів, хворих на гельмінтози. До складу препаратів входять діючи речовини фіпроніл - 100 мг; моксидектин - 25 мг; празиквантел - 40 ме, які вважаються ефективними за кишкових паразитозів у багатьох тварин. Для визначення ефективності препаратів формували умовні групи тварин по 6 гол. в кожній. Вивчали загальний стан хворих та анамнез зі слів господарів тварин. В кожній групі були твварини, в яких перед дегельмінтизацією виявляли асоиійований перебіг нематодозної та цестодозної інвазії за результатами копроовоскопічних досліджень, проведених за методом Котельникова-Хренова. У собак інтенсивність інвазії нематодами і цестодами в середньому по групі складала ,відповідно 80-87 \%, а у котів 53-78 \%. Препарати призначали в рекомендованих виробником дозах собакам масою тіла 1-5 ке - 0,5 мл препарату; масою тіла 5-10 ке - 1 мл, котам масою тіла 1-5 ке - 0,5 мл препарату; масою тіла 5-10 ка - 1 мл препарату. За результатами досліджень було встановлено, що при клінічному випробуванні nрепарату ELITE ZOO ДОГ екстенсефективність проти нематодозів собак (T. canis) становила 100 \%, а проти иестодозів (Ctenocephalides canis) 80 \%. При застосуванні препарату ELITE ZOO KET екстенсефективність проти нематодозів котів (T. cati) становила $100 \%$, а честодозів (Ctenocephalides felis) $100 \%$. Дослідами доведено, що терапевтична ефрективність розчину ELITE ZOO ДОГ при змішаних цестодозах склала 80-87,5 \%. По результатам досліджень виявлена 100 \% ефрективність розчину ELITE ZOO KET при лікуванні котів, інвазованих токсокарами та дипілідіями.

Ключові слова:собаки, коти,гельмінти, нематоди, цестоди, токсокароз, токсаскароз, тенізіоз, дипілідіоз, антигельмінтні препарати: ELITE ZOO ДОГ та ELITE ZOO КET

DOl: https://doi.org/10.32845/bsnau.vet.2020.3.6

Bcmyn. На сьогоднішній день популярним $є$ розведення собак та котів елітних порід. Ці тварини регулярно беруть участь у виставках, змаганнях, тому їхнє переміщення по території країни, а також за її межами $є$ необхідним, тому їх господарі змушені в обов'язковому порядку проводити комплекс профілактичних заходів, що включають і дегельмінтизацію (Бодня Е.И.,2006; Дахно І.С. та ін., 2010; Дубина И.Н., 2006; Есаулова Н.В., 2010; Лисенко А.Я та ін.,. 2002). Собаки $€$ найпопулярнішими домашніми тваринами у всьому світі, але вони часто хворіють на гельмінтози, що може становити загрозу здоров'ю людей, особливо дітей, людей похилого віку та людей із порушеннями імунітету (Лисенко А.Я. та ін.., 2002; Павленко С.В., 2004; Сорока Н.М. та ін., 2010). Власники тварин, які утримуються в приватному секторі, квартирах, не дотримуються елементарних правил санітарії та не прибирають екскременти за своїми улюбленцями і тому відбувається інфікування в першу чергу дітей. Наприклад, Dipylidium caninum, Echinococcus granulosus, Ancylostoma spp. та Toxocara canis є загальними паразитами собак, які можуть вражати людей і ці хвороби зареєстровані у різних країнах світу. Знання про види паразитів у домашніх собак, поширеність та інтенсивність зараження гельмінтами серед популяцій собак, передача собачих паразитів та сезонна динаміка

зараження паразитами $€$ важливими для контролю та профілактики гельмінтозів у домашніх тварин та людей. Дослідження популяцій вільно існуючих собак, як частини міської екології $є$ головним ключем для вирішення багатьох екологічних проблем в промислових екосистемах (Сулейманова Г.Ф, 2000; Черкаський Б. Л., 2006).

Аналіз останніх досліджень і публікацій в яких започатковано розв'язання проблеми. Шлунково-кишкова фауна гельмінтів у собак налічує 21 вид паразитів. Існує вісім видів стрічкових гельмінтів з сімейств Taeniidae, Dipylidiidae, Mesocestoidida та Diphyllobothriidae. Круглі паразити представлені шістьма видами із сімейств Ascarididae, Ancylostomatidae, Strongiloididae та Trichuridae. Серед плоских гельмінтів вияавляють сім видів із родин Opisthorchiidae, Dicrocoeliidae та Diplostomatidae. Деякі види, такі як Toxascaris leonina, T. canis, D. caninum, E. granulosus i A. caninum, часто зустрічаються у собак з різних регіонів України. Діагноз на гельмінтози, що вражають собак, встановлюють шляхом копрологічного обстеження, виявлення личинок (Strongyloides) та посмертним дослідженням. Яйця гельмінтів зазвичай виявляються в калі звичайними копрологічними методами, такими як метод Фюллеборна та метод Дарлінга. Проте ці методи мають низьку чутливість для деяких

\footnotetext{
${ }^{1}$ Науковий керівник: д.вет.н., проф. А.В. Березовський
} 
видів гельмінтів і призводять до недооцінки реальної поширеності деяких паразитів (Bittirov A.M., 2012; Gadzhie I.G. et al., 2010; Kolesnikov V.I. et al., 2012). Деякі методи флотації та седиментації застосовуються лише в країнах СНД. Наприклад, методи Котельнікова-Варенічева та Котельникова-Хренова - це відцентрова техніка флотації, яка має високу чутливість для багатьох видів гельмінтів. Техніка седиментації запропонована Горячевим, даний метод використовують при діагностиці гельмінтозів, збудники яких виділяють яйця з великою щільністю, вони більш трудомісткі ніж методи фолотації, що пов'язано зі складністю відмивання яєць гельмінтів в осаді досліджуваної суміші, запропонована для виявлення яєць опісторхісів, використовується і деякими іншими дослідниками (Lun Z.R. et al., 2005). Проте інші методи копрологічного обстеження, що застосовуються у всьому світі, в Україні переважно не використовують. Наприклад, TF-test@, розроблений для виявлення шлунково-кишкових паразитів людини (Nikolaeva N. et al, 2005) також використовується для виявлення яєць гельмінтів у собак. Деякі порівняльні дослідження показали, що техніка відцентрової фрлотації була більш чутливою, ніж відцентрова седиментація та TF-test $囚$ для виявлення яєць Ancylostoma spp., T. canis, Trichuris vulpisy фрекаліях котів. Іншим методом $є$ техніка Вілліса, що має високу чутливість до яєць T. canis у собачих (Lin R.Q., 2011). Більше того, недавнє дослідження показало, що цей метод виявився кращим, ніж відцентрова техніка флотації та техніка Гофмана-Понса-Жанера для виявлення Ancylostoma spp. у фекаліях собак (Kolesnikov V.I, 2012).

При посмертному дослідженні використовуються методи тотального та часткового гельмінтологічного дослідження, що були запропоновані Скрябіним (King S., 2001), і використовуються у паразитологічних дослідженнях. Більшість видів гельмінтів, що реєструється у собак України, мають зоонозний потенціал. T. canis $€$ найпоширенішим кишковим ендопаразитом у всьому світі. Люди заражаються токсокарозом через контакт з забрудненим ґрунтом яйцями гельмінтів, шерсть домашніх тварин, предмети догляду за тваринами,реманент (Kolesnikov V.I., 2012). Відомо, що чинниками передачі збудників інвазії є саме забруднені яйцями токсокар ґрунт, шерсть тварин, предмети догляду за ними, овочі, столова зелень, руки (Есаулова Н.В., 2000; Лисенко А.Я., .2002; Черкаський Б.Л., 2006).

Проблема токсокарозу у людей та собак висвітлюється у всьому світі. В Україні токсокароз часто реєструється у дітей, з проявом алергічної реакції від 16 \% до 47 \%. Вісцеральний токсокароз частіше реєструється у дорослих. Рівень зараженості в різних регіонах та у людей різних вікових груп в цілому різний. Збудник ехінококозу (E. granulosus) - широко розповсюджений паразит, який завдає великі збитки та соціально-економічні витрати. Існування дорослих паразитів відбувається в тонкому кишечнику собак, і люди заражаються потраплянням в організм зараженої їжі (Abere T. et al., 2013) або при безпосередньому контакті із зараженими собаками шерстний покрив яких забруднений яйцями гельмінтів (Neves D. et al., 2014). Забруднення навколишнього середовища яйцями гельмінтів $є$ великою проблемою в багатьох міських і сільських районах України. Так, рівень забрудненості ґрунту яйцями геогельмінтів коливається в межах 3-9 \%, у той же час від 29 до 48 \% проб ґрунту з виявленими збудниками паразитозів містять яйця токсокар; у ґрунті на території дитячих закладів їх частка досягає 58-67 \%, на дитячих майданчиках житлових будинків - $90 \%$, на пляжах - від 86 до 100 \% позитивних проб (Paliy A. et al., 2019).

Інтенсивність екскреції яєць статевозрілими гельмінтами, що населяють кишечник тварин, стійкість яєць у зовнішньому середовищі - все це є визначальними факторами поширення інвазії. Обстеженнями проведеними в різних країнах, встановлена значна забрудненість ґрунту в населених пунктах яйцями гельмінтів, з коливаннями від 2,9 до 60 \% позитивних проб (Субботин А.М., 2012; Дубина И.Н., 2006; Черкаський Б.Л., 2006; Галатюк О.Є. та ін.., 2018). Отже, за наявності результатів санітарно-гельмінтологічного дослідження ґрунту на територіях регіону можна прогнозувати ризик інвазування людей токсокарозом.

Ехінококоз людини є найсерйознішим паразитарним захворюванням, оскільки летальний кінець настає у 2-23\% випадків (Overgaauw P.A. et al., 2009). Найпоширенішою хвороба є у Китаї, західній та південній частині Росії, ПівденноЗахідній Європі, Південній Африці та Центральній та Південній Америці (Masse G. et al., 2017). В останні роки були проведені дослідження на основі ДНК і встановлено, що $E$. granulosus містить 10 генотипів, які були виділені у різних видів. E. granulosus s. s. (G1-G3), E. canadensis (G6, G8 i G10) виявлені в Україні. Люди рідко заражаються $D$. caninum, який виникає через потрапляння в організм котячих бліх, заражених ланцюжковими гельмінтами, але така інвазія теж зареєстрована в Україні. В зв'язку з цим контроль та профілактика гельмінтозних зоонозів $€$ актуальною ветеринарною та медичною проблемою. T. canis та E. granulosus, які мають поширення у всьому світі однак офріційних рекомендацій щодо контролю цих інвазій у собак не існує, в таких як рекомендації Companion Animal Parasite Council (CAPC: http://www.capcvet.org/) у США та European Scientific Counsel Companion Animal Parasites (ESCCAP: http://www.esccap.org/) в Європі.

Моніторинг паразитарних захворювань здійснюється нерегулярно. Велика кількість безпритульних собак, неконтрольоване використання протипаразитарних препаратів спричиняють забруднення навколишнього середовища яйцями гельмінтів (Soroka N.M. et al., 2010).

Знання видового складу гельмінтів у собак, вивчення поширення гельмінтозів, екстенсивності і інтенсивності інвазії, а також вікової та сезонної динаміки необхідно для визначення епізоотології гельмінтозів домашніх м'ясоїдних тварин і епідеміології інвазійних хвороб. Це допоможе більш правильно і ефективно проводити профілактичні та лікувальні заходи за даних паразитозів та допоможе запобігти активному розповсюдженню збудників гельмінтів. В даний час основні методи профілактики зараження гельмінтами собак включають регулярну дегельмінтизацію домашніх тварин, контроль забруднення навколишнього середовища (уникати забруднення фекаліями собак в громадських місцях) та поширення інсормації про зоонозних паразитів (Suleymanova G.F., 2000). Більше того, контроль якості їжі та дієти домашніх тварин допомагають запобігти зараженню паразитами. Багато власників собак не можуть дозволити собі профрілактичні заходи і діятимуть лише тоді, коли проблема, що загрожує життю, стосується їх тварин. Державні установи не можуть керувати цими процесами в повному обсязі через відсутність належної інфраструктури та навченого персоналу для прове- 
дення ефективної довгострокової програми контролю популяції. Як наслідок, домашнім собакам і котам зазвичай загрожує широкий спектр паразитів, які можуть спричинити захворювання у них. Тісний контакт між домашніми тваринами та людьми може мимоволі представляти небезпеку для людей. Тому, щоб уникнути потенційних ризиків інфікування людини від тварини принципово важливо утримувати домашніх тварин у доброму здоров'ї. Тому ветеринарні лікарі та медичні лікарі повинні спільно працювати над покращенням добробуту та загального стану здоров'я як тварин, так і людей. Останніми роками не завжди проводилось достатня кількість наукових досліджень направлених на вивчення інсекційної та інвазійної патології даних тварин. Пероральне застосування препаратів у вигляді таблеток, розчинів, суспензій, паст у дрібних тварин часто супроводжується проблемами як із їх застосуванням (агресія тварин), так і з наслідками - піна зі слини,блювання та ін. Тому актуальним є розробка нових засобів профрілактики гельмінтозів та лікування домашніх тварин уражених гельмінтами для зовнішнього застосування, точкового нанесення на шкіру тварини за допомогою ампуликрапельниці у місця, недоступні для злизування.

Зв'язок роботи 3 науковими програмами, планами темами. Робота виконувалася на кафедрі ветсанекспертизи мікробіології, зоогігієни та безпеки і якості продуктів тваринництва Сумського НАУ за наступним тематичним планом нау ково-дослідної роботи «Прогнозування ризиків транскордон ного заносу та поширення особливо небезпечних хвороб тварин та розробка науково обґрунтованих систем дезінфекції на основі інноваційних імпортозамінних високоефективних за собів» (№ державної реєстрації 0115 U 001342, 2018-2023рр.)

Метою нашої роботи було визначення ефективності нових експериментальних препаратів ELITE ZOO ДОГ та ELITE ZOO КET (ООО фірма ПРОДУКТ) для лікування собак і котів за складних кишкових паразитоценозів.

Матеріали і методи. Дослідження проводили в умовах ветеринарної клініки «Ветсервис» міста Суми та на кафедрі епізоотології та паразитології Сумського національного аграрного університету. Собак з мікст інвазіями кишковими збудниками відбирали за результатами копроовоскопічних досліджень проведених за методом Котельникова- Хренова. Для випробування препарату ELITE ZOO ДОГ формували умовну групу з 30 безпородних собак різної статі, спонтанно інвазованих Toxascaris leonine, нематодами сімейства Ancylostomatidae i Toxocaracanis.

Інвазованих гельмінтами котів відбирали за результатами копроовоскопічних досліджень і розподіляли на групи в залежності від ступеня їх інвазованості та виду гельмінтів. В дослід було взято 20 тварин спонтанно вражених токсокарами та дипілідіями. Ефективність розраховували на основі результатів копроовоскопічних досліджень, кількості гельмінтів в 1 г біоматеріалу до та після використання препарату ELITE ZOO KET.

Препарат ELITE ZOO KET (розчин для зовнішнього застосування, точкового нанесення) - прозора масляниста рідина від світло-жовтого до темно-жовтого кольору зі специ- фрічним запахом складових компонентів. 1 мл препарату містить діючі речовини: фіпроніл - 100 мг; моксидектин - 10 мг; празиквантел - 40 мг. Складові препаратів: фіпроніл-5-аміно1-[2,6-дихлоро-4-(трифрлуорометил)феніл]-4-[(трифлуорометил) сульфінил]-1Н-піразол-3-карбонітрил феенілпіразолу. Механізм дії фріпронілу у безхребетних полягає в гальмуванні проходження іонів хлору в залежних хлоридних каналах, що порушує роботу нервової системи членистоногих. Через системне блокування фіпронілом нервової системи настає нервове перезбудження і загибель ектопаразитів; моксидектин напівсинтетична сполука групи мільбеміцинів (макроциклічні лактони) стимулює виділення ГАМК та, зв'язуючись із постсинаптичними рецепторами, викликає порушення м'язової іннервації, параліч та загибель ектопаразитів та нематод; празиквантел - похідне піразинізохіноліну, діє на більшість видів цестод (у тому числі на їх личинкові стадії) та трематоди викликає деполярізацію нейром'язових гангліїв, порушення транспортування глюкози та мікротубулярної функції у цестод, що призводить до паралічу та загибелі паразитів.

Препарат ELITE ZOO ДОГ застосовували зовнішньо, наносили на суху, неушкоджену шкіру тварини за допомогою ампули-крапельниці у місця, недоступні для злизування (на холку та вздовж хребта), у дозах: собакам масою тіла 1-5 кг 0,5 мл препарату; масою тіла 5-10 кг - 1 мл препарату; масою тіла 10-20 кг - 2 мл препарату; масою тіла 20-30 кг - 3 мл препарату; масою тіла 30-40 кг - 4 мл препарату; масою тіла 4060 кг - 6 мл препарату.

ELITE ZOO KET застосовували зовнішньо, наносили на суху, неушкоджену шкіру тварини за допомогою ампуликрапельниці у місця, недоступні для злизування (на холку), у дозах: котам масою тіла 1-5 кг - 0,5 мл препарату; масою тіла 5-10 кг - 1 мл препарату.

Антигельмінтну ефективність ELITE ZOO дОГ розраховували на підставі результатів копроовоскопічних досліджень, оцінюючи кількість яєць гельмінтів в 1 г біоматеріалу до введення препарату та через 7-10 днів після застосування препарату.

Антигельмінтна ефективність при цестодозах була вивчена на 30 собаках віком старше 6 років, що були спонтанно інвазовані дипілідіями та теніями і утримувались у притулку. Оцінка ефективності препарату проводилась на 7-10й день після лікування за допомогою копроовоскопічних дослідженнь методом Щербовича. Собак годували сухим збалансованим кормом фірми «Josera», доступ до води не обмежений.

Антигельмінтну ефрективність препарату ELITE ZOO КЕТ за змішаної інвазії цестод та нематод вивчали на умовній групі з 20 котів віком старше 4 років, яких утримували в приватних помешканнях м. Тростянець Сумської області. Після встановлення рівня мікст інвазії застосовували препарат ELITE ZOO KET тваринам з масою тіла 1-5 кг - 0,5 мл, а з масою тіла 5-10 кг - 1 мл препарату. Котів годували сухим кормом «Мяу», а також рибою та сирою яловичиною.

Результати досліджень щодо ефективність препарату ELITE ZOO ДОГ при мікстінвазії круглих гельмінтів - токсаскар, токсокар та анкілостом представлено в таблиці 1. 


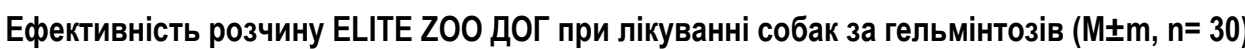

\begin{tabular}{|l|c|c|c|c|c|}
\hline \multirow{2}{*}{ Гельмінтоз } & \multicolumn{3}{|c|}{ Кількість інвазованих собак } & $\begin{array}{c}\text { Інтенсесективність, } \\
\%\end{array}$ & \multicolumn{2}{|c|}{$\begin{array}{c}\text { Кількість яєць гельмінтів } \\
\text { в } 1 \text { г фекалій }\end{array}$} & $\begin{array}{c}\text { Ефективність лікування } \\
\text { (екстенсефектив- } \\
\text { ність),\% }\end{array}$ \\
\cline { 2 - 6 } & до лікування & після лікування & & до лікування & після лікування \\
\hline Токсаскаріо3 & 14 & 0 & 100 & $60,0 \pm 3,0^{*}$ & 0 \\
\hline Токсокаро3 & 11 & 0 & 100 & $81,4 \pm 4,1^{*}$ & 0 \\
\hline Анкілостом03 & 5 & 0 & 100 & $76,7 \pm 3,8^{*}$ & 0 \\
\hline
\end{tabular}

На наступному етапі були проведені дослідження по вивченню ефективності препарату ELITE ZOO ДОГ при лікуванні собак за змішаних цестодозів. Дослідами доведено, що терапевтична ефективність розчину ELITE ZOO ДОГ при змішаних цестодозах склала 80-87,5\% (таблиця 2).

Таблиця 2

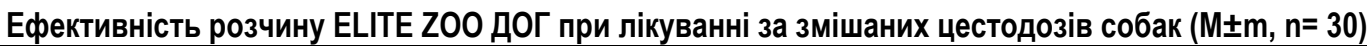

\begin{tabular}{|l|c|c|c|c|c|}
\hline \multirow{2}{*}{ Захворювання } & \multicolumn{2}{|c|}{ Кількість інвазованих собак } & \multirow{2}{*}{ Інтенсефективність, \%, } & \multicolumn{2}{|c|}{ Кількість яєць гельмінтів 1 г фекалій , } \\
\cline { 2 - 3 } & до лікування & після лікування & & дікування & після лікування \\
\hline Дипілідіоз & 16 & 2 & $87,5 \pm$ & $153,4 \pm 7,7^{*}$ & $29,2 \pm 1,5^{*}$ \\
\hline Теніоз & 5 & 1 & $80,0 \pm$ & $126,2 \pm 6,3^{*}$ & $13,8 \pm 0,7^{*}$ \\
\hline
\end{tabular}

Примітка: * $P \leq 0,05$

Інвазованих гельмінтами котів відбирали за результатами копроовоскопічних досліджень і розподіляли на групи в залежності від ступеню їх інвазованості та виду гельмінтів. В дослід було взято 20 тварин спонтанно вражених токсокарами та дипілідіями. Ефективність розраховували на основі результатів копроовоскопічних досліджень кількість яєць гельмінтів в 1 г біоматеріалу до та після використання препарату ELITE ZOO KET. Отримані результати наведені в таблиці 3.

Таблиця 3

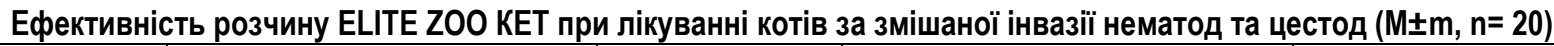

\begin{tabular}{|c|c|c|c|c|c|c|}
\hline \multirow{2}{*}{ Захворювання } & \multicolumn{2}{|c|}{ Кількість інвазованих котів } & \multirow{2}{*}{$\begin{array}{c}\text { Інтенсефективність, } \\
\%\end{array}$} & \multicolumn{2}{|c|}{ Кількість яєць гельмінтів в 1 г фекалій } & \multirow{2}{*}{ Екстенсефрективність, \% } \\
\hline & до лікування & після лікування & & до лікування & після лікування & \\
\hline Токсокароз & 15 & 0 & 100 & $76,7 \pm 3,8^{*}$ & 0 & 100 \\
\hline Дипілідіоз & 5 & 0 & 100 & $53,1 \pm 2,7^{*}$ & 0 & 100 \\
\hline
\end{tabular}

Примітка: * $P \leq 0,05$

За результатами досліджень виявлена 100\% ефективність розчину ELITE ZOO KET при лікуванні котів інвазованих токсокарами та дипілідіями.

Обговорення отриманих результатів. Проведені дослідження показали наступне. Застосування препаратів ELITE ZOO ДOГ та ELITE ZOO KET в формі крапель на шкіру під час лікування дрібних домашніх тварин (собак та котів) за асоційованих нематодозів та цестодозів довело їх ефективність в межах 80 - 100 \%, тому дані препарати можна вважати досить ефективними при асоційованих інвазіях токсокарозу, дипілідіозу, теніозів в рекомендованих виробником дозах: собакам масою тіла 1-5 кг - 0,5 мл препарату; масою тіла 510 кг - 1 мл препарату; масою тіла 10-20 кг - 2 мл препарату; масою тіла 20-30 кг - 3 мл препарату; масою тіла 30-40 кг -
4 мл препарату; масою тіла 40-60 кг - 6 мл препарату. Котам у дозах: масою тіла 1-5 кг - 0,5 мл препарату; масою тіла 510 кг - 1 мл препарату.

Висновки. При використанні препарату ELITE ZOO ДОГ в рекомендованій концентрації ефективність при змішаних цестодозах собак складає 80-87,5 \% а при застосуванні ELITE ZOO KET ефективність при лікуванні котів, інвазованих токсокарами та дипілідіями складає $100 \%$

Перспективи подальших досліджень. Подальші дослідження будуть скеровані на визначення іншого видового складу гельмінтів собак та котів, а також використання розроблених препаратів ELITE ZOO ДОГ та ELITE ZOO KET з метою дегельмінтизації дрібних тварин.

\section{References:}

1.Bodnya E.I. (2006). Toksokaroz - parazitarnoye zabolevaniye zhivotnykh i cheloveka [Toxocariasis - a parasitic disease of animals and humans ]. Zhurnal suchasnoho likarya. Mystetstvo likuvannya [Journal of the modern doctor. The art of healing], 6(32), 57-59 [in Ukrainian].

2.Dakhno I.S., Dakhno Y.I. (2010). Ekolohichna hel'mintolohiya. Navchal'nyy posibnyk Ecological helminthology. Tutorial. [Ecological helminthology. Tutorial]. Sumy: Kozats'kyy val [ Sumy: Cossack shaft,], 77-82 [in Ukrainian].

3.Dubina I.N. (2006). Gel'mintozysobak: monografiya [Helminthiasis of dogs: a monograph]. Journal of the Vitebsk, 200. Journal of the Vitebsk

4.Esaulova N.V. (2000). Gel'mintozy sobak i koshek, opasnyye dlya cheloveka i ikh diagnostika. [Helminthiasis of dogs and cats, dangerous to humans and their diagnosis] veterinariya [Veterinary], 6, 22-28.

5.Lysenko A.Ya., Vladimirova N.G., Kondrashina A.K. (2002). Klinicheskaya parazitologiya. [ Clinicalparasitology] Journal of the Geneva, 65-66.

6.Pavlenko S.V. (2004) Hel'mintozy sobak mis'kykh populyatsiy: poshyrennya, terapevtychna ta imunolohichna otsinka kompleksnoyi terapiyi: avtoref. dys. ... kand. vet. nauk: spets. 16. 00.11. «Parazytolohiya, hel'mintolohiya» [Helminthiasis of dogs of urban 
populations: prevalence, therapeutic and immunological assessment of complex therapy: author's ref. dis. cand. vet. Science: special. 16. 00. 11. "Parasitology, helminthology"] Kharkiv, 20 [in Ukrainian].

7.Soroka N.M., Dakhno I.S. (2010). Hel'mintofauna sobak tsentral'noyi chastyny Ukrayiny [Helminthfauna of dogs of thecentral part of Ukraine]. Naukovyy visnyk NUBiP Ukrayiny [Scientific Bulletin of NULES of Ukraine ], 151 (2), 176-178 [in Ukrainian].

8.Bittirov A.M., Mantaeva S.S., Shihalieva M.A., Sarbasheva M.M., Bidzhiev A.Z., Golubev A.A. and Akieva O.M. (2012). Jepizootologicheskaja ocenka gel'mintov sobak i dikih psovyh v Kabardino-Balkarii (Epizootological evaluation of dogs and wild canis helminthes in Kabarino-Balkarian Republic). Agrarnaja Nauk., 9: 31-32 [In Russian].

9.Gadzhiev I.G, Ataev A.M, Gazimagomedov M.G. (2010). Fauna of helminthes of domestic and wild Canidae in the plane zone of Dagestan. Russ. J. Parasitol. 2010; 4:12-15., DOI: 10.14202/vetworld.2016.1248-1258 [in England].

10. Kolesnikov V.I., Popov O.V. (2012) Fauna of helminths of dogs in region the caucasus mineral waters. Nauchno Proizvodstvennyj Zhurnal Ovcy, Kozy, Sherstjanoe Delo. 2012;4:49-52. DOI: 10.14202/vetworld.2016.1248-1258 [in England].

11. Lun Z.R., Gasser R.B., Lai D.H., Li A.X., Zhu X.Q., Yu X.B., Fang Y.Y. (2005) Clonorchiasis: a key foodborne zoonosis in China. Lancet Infect Dis. 2005 Jan; 5(1): 31-41. doi: 10.1016/S1473-3099(04)01252-6. PMID: 15620559 [in England].

12. Nikolaeva N., Nikolaeva L., Gigileva N. (2005) Opistorhoz (Jepidemiologija, Klinika, Diagnostika, Lechenie), [Opistorchosis (Epidemiology, clinic, diagnostics and treatment)] Vrach. 2005;7:17-20 [In Russian].

13. Cherkassky B. L. (2006). Ponyatiye «risk» vepidemiologii [The concept of "risk" in epidemiology]. Epidemiologiya i infekts. bolezni. [Epidemiology and infectious diseases il], 4-10 [in Russian].

14. Abere T., Bogale B. and Melaku A. (2013). Gastrointestinal helminth parasites of pet and stray dogs as a potential risk for human health in Bahir Dar town, North-Western Ethiopia. Vet. World, 6: 388-392.https:/doi.org/10.5455/vetworld.2013.388-392 [in England]

15. Neves D., Lobo L., Simoes P.B. and Cardoso L. (2014). Frequency of intestinal parasites in pet dogs from an urban area (Greater Oporto, northern Portugal). Vet. Parasitol., 200: 295-298.https:/doi.org/10.1016/i.vetpar.2013.11.005PMid:24433853 [in England].

16. Paliy A., Sumakova N., Petrov R., Shkromada O., Ulko L., \& Palii, A. (2019). Contamination of urbanized territories with eggs of helmiths of animals. Biosystems Diversity, 27(2) , 118-124. doi:10.15421/01191 [in England].

17. Subbotin A.M. (2012). Gel'minty kak osnovnoy component parazitarnoy sistemy zhivotnykh [Helminths as the main component of the parasitic system of animals] Uchenyye zapiski uchrezhdeniya obrazovaniya «Vitebskaya gosudarstvennaya akademiya veterinarnoy meditsiny» nauchno-prakticheskiy zhurnal. [Scientific notes of the educational institution "Vitebsk State Academy of Veterinary Medicine" scientific and practical journal], 48(1) 203-206. [in Belarus].

18. Galatyuk O.Y., Peredera O.O., Lavrinenko I.V., Zhernosik I.A. (2018). Infektsiyni khvoroby sobak. [Infectious diseases of dogs]. Navchal'nyy posibnyk dly avuziv II-IV rivniv akredytatsiyi [Navchalnyy booklet for universities II - IV accreditation rivniv], Zhytomyr, 276 [in Ukrainian].

19. Overgaauw P.A., van Zutphen L., Hoek D., Yaya F.O., Roelfsema J., Pinelli E., van Knapen F., Kortbeek L.M. (2009). Zoonotic parasites in fecal samples and fur from dogs and cats in The Netherlands. Vet Parasitol. 2009 Jul 7;163(1-2):115-22. doi: 10.1016/j.vetpar.2009.03.044. Epub 2009 Apr 5. PMID: 19398275 [in England].

20. Massei G., Fooks A.R., Horton D.L., Callaby R., Sharma K., Dhakal I.P., Dahal U. (2017). Free-Roaming Dogs in Nepal: Demographics, Health and Public Knowledge, Attitudes and Practices. Zoonoses Public Health. Feb;64(1):29-40. doi: 10.1111/zph.12280. Epub 2016 Jun 23. PMID: 27334892 [in England].

21. Suleymanova G.F. (2000). Zarazhennost' plotoyadny k hrazlichnymi vidami parazitov. [Infection of carnivores with various types of parasites] Metody povysheniya produktivnykh i zashchitnykh funktsiy organizma zhivotnykh v RB. — Ufa [Methods for increasing the productive and protective functions of animals in the Republic of Belarus. - Ufa], 213-214 [in Russian].

A.V. Berezovsky, Dr, professor, Sumy National Agrarian University (Sumy, Ukraine)

B.S. Morozov, PhD studend, Sumy National Agrarian University (Sumy, Ukraine)

The effectiveness of "ELITE ZOO DOG" and "ELITE ZOO KET" on the helminth fauna of small pets

This article provides data on the use of ELITE ZOO DOG and ELITE ZOO KET for the treatment of pathogens of helminthiasis in the veterinary clinic "Vetservice" in the city of Sumy. According to the research results, it was found that the effectiveness of the drug against intestinal helminthiasis on average reaches $80 \%$. After application of the drug, helminthiases were recorded as monoinvasion. The vast majority of pathogens of helminthiasis belonged to the Teniosis class. The purpose of our work: was to determine the effectiveness of new experimental drugs ELITE ZOO DOG and ELITE ZOO KET, to determine the activity of helminths after the use of this drug in the veterinary clinic "Vetservice" in Sumy. The research was conducted in the veterinary clinic "Vetservice" in Sumy and at the Department of Epizootology and Parasitology of Sumy National Agrarian University. Dogs infested with nematodes were selected based on the results of coprooscopic studies performed by the method of Kotelnikov-Khrenov. Thus, in a clinical trial of ELITE ZOO DOG and ELITE ZOO KET, their effectiveness in the treatment of nematodes and cestodes of small animals (dogs and cats) was proven. The effectiveness of drugs reaches from 80 to $100 \%$ and therefore these drugs can be considered quite effective in certain types of helminthiasis. The drug ELITE ZOO DOG (solution for external use, spot application) - a clear oily liquid from light yellow to dark yellow with a specific odor of the constituent components. $1 \mathrm{ml}$ of the drug contains active substances: fipronil - $100 \mathrm{mg}$; moxidectin - $25 \mathrm{mg}$; praziquantel - $40 \mathrm{mg}$. ELITE ZOO KET (solution for external use, spot application) - a clear oily liquid from light yellow to dark yellow with a specific odor of the components. $1 \mathrm{ml}$ of the drug contains active substances: fipronil - $100 \mathrm{mg}$; moxidectin - $10 \mathrm{mg}$; praziquantel - 40 mg. Fipronil - 5-amino-1- [2,6-dichloro-4- (trifluoromethyl) phenyl] -4- [(trifluoromethyl) sulfinyl]-1H-pyrazole3-carbonitrile phenylpyrazole. The mechanism of action is depolarization of neuromuscular ganglia, impaired glucose transport and 
microtubular function in cestodes, leading to paralysis and death of parasites. It is proved that the drugs should be applied externally, applied to dry, intact skin of the animal with an ampoule-dropper in places inaccessible to lick (on the withers and along the spine), in doses: dogs weighing 1-5 kg - $0.5 \mathrm{ml}$ of the drug ; body weight $5-10 \mathrm{~kg}-1 \mathrm{ml}$ of the drug; body weight $10-20 \mathrm{~kg}-2 \mathrm{ml}$ of the drug; body weight 20-30 kg - $3 \mathrm{ml}$ of the drug; body weight 30-40 kg - $4 \mathrm{ml}$ of the drug; body weight 40-60 kg - $6 \mathrm{ml}$ of the drug. Cats in doses: body weight $1-5 \mathrm{~kg}-0.5 \mathrm{ml}$ of the drug; body weight $5-10 \mathrm{~kg}-1 \mathrm{ml}$ of the drug.

Key words: helminths, carnivore, nematodes, cestodes, intensity invasion, extensivity invasion, toxocarosis, toksaskarosis, ankilostomosis, teniosis, dypilidiosis

Дата надходження до редакції: 12.11.2020 р. 